\title{
Relevansi Nilai Lokasamgraha Terhadap Wacana Politk Identitas Dan Masa Depan Kebangsaan
}

\author{
Puspo Renan Joyo ${ }^{1}$, Mujiyono ${ }^{2}$, Kadek Ayu Ariningsih ${ }^{3}$ \\ ${ }^{12}$ Institut Agama Hindu Negeri Tampung Penyang Palangka Raya \\ ${ }^{3}$ STMIK STIKOM Indonesia \\ ${ }^{1}$ pusporenanjoyo@iahntp.ac.id, ${ }^{2}$ mujiyono@iahntp.ac.id, ${ }^{3}$ ayuari@ stiki-indonesia.ac.id
}

\begin{abstract}
This article is a study of national identity, identity politics, and the value of Lokasamgraha in Hinduism and their relevance to the escalation of identity politics and the discourse of the future of the nation. This is a library research with qualitative approach. Lokasamgraha is a material object in this research. This research used data collection techniques and using data analysis, namely: interpretative, holistic and descriptive. Results of this study are: 1) national identity is Bhinneka Tunggal Ika inspired by Pancasila and Undang-Undang Dasar 1945, and explored into three, fundamental identity, instrumental identity, and natural identity; 2) identity politics is irrelevant and has lost its meaning. The emergence of identity politics lately must be viewed as a threat and sabotage against the existence of Indonesia. And the last is 3) the value of Lokasamgraha is at odds with identity politics but found similar resonance with the discourse on the future of the nation. Lokasamgraha finds its urgency in two things, namely: identity politics and the future of nation.
\end{abstract}

Keywords: Identity Politics; Lokasamgraha; National Identity, The Future of the Nation

\section{Abstrak}

Artikel ini adalah studi tentang tentang identitas nasional, politik identitas dan nilai lokasamgraha dalam agama Hindu relevansinya dengan eskalasi politik identitas dan wacana masa depan kebangsaan. Penelitian adalah studi kepustakaan dan jenis penelitian adalah kualitatif. Lokasamgraha merupakan objek material dalam penelitian ini. Studi dokumen merupakan teknik pengumpulan data dalam penelitian ini. Penelitian ini menggunakan teknik pengumpulan data studi dokumen penelitian ini menggunakan analisis data dengan langkah-langkah metodis analisis deskriptif, interpretatif dan holistika. Temuan penelitian ini adalah: 1) Identitas nasional adalah Bhineka Tunggal Ika atas dasar Pancasila dan Undang-Undang Dasar (UUD) 1945, yang di ekplanasi menjadi tiga identitas, yaitu; fundamental, instrumental, dan alamiah. 2) politik identitas tidak relevan dan telah kehilangan makna. Munculnya politik identitas belakangan ini harus dipandang sebagai ancaman dan sabotase terhadap eksistensi bangsa Indonesia. 3) Nilai Lokasamgraha berseberangan dengan politik identitas namun menemukan kesamaan resonansi dengan wacana masa depan kebangsaan. Lokasamgraha menemukan urgensinya dalam dua hal, yaitu: politik identitas dan masa depan kebangsaan.

Kata Kunci: Identittas Nasional; Lokasamgraha; Masa Depan Bangsa; Politik Identitas

\section{Pendahuluan}

Insight paling awal tentang Indonesia adalah dimensi pluralitas yang secara inheren ada sejak kelahirannya. Pengertian ini menjadi aspek fundamental yang harus dimiliki dan disadari oleh setiap individu sebagai bekal sebelum melangkahkan kaki lebih jauh dalam perjalanan mpanjang sebagai manusia Indonesia. Keniscayaan keragaman ini, 
secara keimanan merupakan hadiah tersembunyi dari Tuhan yang patut di syukuri, karena bangsa ini telah diijinkan untuk mengenal, memahami, dan belajar tentang kenyataan dan asas paling purba dari kehidupan ini. Indonesia adalah wujud paling kasat mata dari pengertian kemajemukan sebagaimana yang telah diperkenalkan Furnival di dunia Barat (Masyrullahushomad, 2019:86).

Berbeda dengan wilayah Asia Tenggara lainnya, seperti; Singapura, Brunai Darussalam, Timor Leste, Kamboja, dan Laos, Negara Indonesia menjadi yang memiliki wilayah terluas, dengan ribuan pulau, adat istiadat dan kebudayaan yang tak tertandingi. Dari Sabang sampai Marauke, dan Miangas hingga pulau Rote, teritorial Indonesia adalah tempat dari 17.499 pulau. Keseluruhan teritorial Indonesia mencapai 7,81 juta km² , yaitu; darat 2,01 juta $\mathrm{km}^{2}$, laut 3,25 juta $\mathrm{km}^{2}$, serta Zona Ekonomi Eksklusif (ZEE) 2,55 juta $\mathrm{km}^{2}$. Perairan Indonesia melebihi daratan, karenanya Indonesia adalah negara maritim (Roza, 2017:2). Berdasarkan laporan yang dirilis Badan Pusat Statistik tentang proyeksi jumlah penduduk tahun 2020, Indonesia memiliki kekayaan demografi yang luar biasa, yakni 269,6 juta jiwa. Dari sisi religiositasnya, Indonesia adalah negara dengan 6 agama dan denominasinya, serta pemeluk kepercayaan yang tersebar di seluruh nusantara. Keragaman etnisitas dan Bahasa terdiri dari 1.340 suku bangsa, dan 2.500 bahasa (Badan Pusat Statistik, 2020:3; Na'im \& Syaputra, 2011:5-7).

Indonesia adalah sebuah bangsa dengan panorama ragam wajah, bukan satu wajah. Realitas ini menjadikan Indonesia memiliki uniqueness yang tidak dimiliki oleh setiap negara di dunia ini. Menyadari pluralitas ini, para founding father telah dengan sangat bijaksana mengikatnya dalam satu simpul kebangsaan Bhineka Tunggal Ika. Pancasila dan UUD1945 menjadi media perekat dan kekuatan yang menyatukan (the integrating force) di tengah kemajemukan bangsa (Asshiddiqie, 2011:13). Menanggapi keragaman Indonesia, Joko Widodo, Presiden Indonesia ke-7 menyatakan bahwa Indonesia dengan identitas dirinya yang majemuk ini merupakan kenyataan yang telah selesai. Kemajemukan telah dituntaskan karena telah menjadi konsensus nasional (Kawangung, 2019:161).

Demografi, kekayaan alam, keragaman Indonesia adalah fondasi kemajuan bangsa Indonesia. Namun situasi saat ini menunjukkan kenyataan yang bertolak belakang. Persoalan pluralitas justru menjadi faktor yang melemahkan (Muhtar, 2019:398). Kontestasi elektoral yang sarat dengan politik identitas menjadi salah satu yang mentrigger polarisasi sosial, hingga polarisasi yang disebabkan oleh identitas primordial. Hasil survei LIPI tahun 2018 mengungkapkan, politik berbasis suku, agama, ras, antar golongan, berimbas terhadap penguatan demokrasi Indonesia (Triguna, 2019:47). Beberapa kajian juga menunjukkan relasi kontestasi elektoral dan politik identitas pada pemilihan kepala daerah di berbagai wilayah di Indonesia juga menimbulkan persoalanpersoalan yang bersentuhan dengan isu-isu identitas (Al Qurtuby, 2018:52-53; Khamdan \& Wiharyani, 2018:198; Muhtadi, 2018:69-70; Romli, 2019:79; Shofan, 2018:4-6).

Menurut Magnis Suseno, menguatnya fenomena politik identitas yang terjadi belakangan ini harus dipandang sebagai bentuk pelemahan sekaligus ancaman serius bagi keadilan, kedamaian, saling menghargai, kesejahteraan dan kesatuan bangsa (Suseno, 2018:12-13). Tindakan Eksploitasi politik politisasi agama secara berlebihan dan cenderung overdosis, brutal, tanpa mengindahkan etika sosial dan rasa kemanusiaan telah menyebabkan rontoknya sendi-sendi kemanusiaan dan runtuhnya nilai persaudaraan universal (Al Qurtuby, 2018:52-54).

Berdasarkan latar belakang tersebut, penelitian ini membahas tiga hal, yaitu; identitas nasional, politik identitas, dan nilai lokasamgraha dalam menyikapi fenomena politik identitas dan wacana masa depan kebangsaan. Tujuan penelitian ini adalah mengungkap nilai lokasamgraha dan relevansinya dengan politik identitas serta wacana 
masa depan kebangsaan. Kajian terdahulu tentang politik identitas, identitas nasional dan kebangsaan telah dilakukan oleh beberapa ilmuwan atau akademisi, tiga diantaranya adalah:

Pertama, artikel karya Romo Magnis tentang politik identitas (2018) yang dipublikasikan pada jurnal 'Maarif Institute for Culture and Humanty' (Suseno, 2018:713). Kajian ini mengupas mengenai historisitas populisme dan politik identitas yang terlahir dari situasi perlawan atas kolonialisme sebuah bangsa atas bangsa lainnya, atau sebuah ketertindasan dan ketidakadilan. Aktualisasi politik identitas di Indonesia dipandang tidak relevan dan sebuah tindakan sabotase terhadap eksistensi Indonesia Tidak ada ruang bagi politik identitas atau populisme karena segala bentuk hukum dan penyelesaikan persoalan negara dan penyelesaiannya telah diatur berdasarkan ideologi dan konstitusi bangsa, yang telah menjadi konsensus nasional dan paripurna. Politik identitas atau populisme merupakan ancaman keutuhan bangsa Indonesia yang majemuk. Kajian Suseno memberikan kontribusi penting dalam penelitian ini, terutama pada aspek historisitas politik identitas dan populisme, namun belum dijumpai adanya pembahasan tentang lokasamgraha dan korelasinya dengan politik identitas serta wacana kebangsaan.

Kedua, "Pancasila sebagai Pengawal Solidaritas Kebangsaan", kajian dari Siswanto dari Pusat Penelitian Politik LIPI (2019), mengupas fenomena politik identitas dalam politik elektoral dan merosotnya solidaritas kebangsaan. Kajian ini menawarkan Pancasila sebagai ideologi bangsa dalam menjawab tantangan solidaritas kebangsaan. Pancasila mengandung tiga dimensi fundamental yang memiliki urgensinya saat ini, yaitu dimensi realitas, dimensi ideal dan dimensi fleksibilitas. Menurutnya, Pancasila sebagai pandangan hidup mulai ditinggalkan. Karenanya, reinterpretasi Pancasila di pandang penting agar selaras dengan semangat reformasi, serta dapat kembali diterima masyarakat (Siswanto, 2019:109-124). Penelitian Siswanto memberikan wawasan tentang solidaritas kebangsaan, fenomena politik identitas dan peran Pancasila dalam menjawab tantangan kedua hal tersebut. Gagasan siswanto tentang Pancasila sebagai jalan alternatif dalam persoalan solidaritas dan politik identitas, menunjukkan disparitas dengan penelitian penulis saat ini yang menawarkan gagasan lokasamgraha sebagai alternatif.

Ketiga, penelitian Afifah (2018) mengurai identitas nasional yang dikelompokkan menjadi tiga identitas; fundamental, instrumental dan alamiah (Afifah, 2018:187-198). Penelitian Afifah memberikan wawasan tentang identitas nasional sebagai fondasi penting dalam melihat ke-Indonesia-an secara menyeluruh. Dengan pemahaman yang komprehensif tentang Indonesia akan memberikan implikasi bagi negara dan masyarakat di dalam mengambil kebijakan, berinteraksi dan ber-etika sosial. Fokus penelitian Afifah tentang indentitas nasional turut memberikan bagi penelitian penulis khususnya terkait dengan wawasan kebangsaan.

Mencermati kajian-kajian sebelumnya, terdapat perbedaan pada aspek kajian dan kebaruannya (novelty) atas studi ini. Pada aspek kajian, penelitian ini mengkaji nilai Lokasamgraha, Politik Identitas dan Wacana Masa Depan Kebangsaan. Pada aspek kebaruannya (novelty), penelitian ini menawarkan gagasan dari nilai lokasamgraha sebagai referensi, alternatif pemikiran atau problem solving atas fenomena politik identitas dan wacana masa depan kebangsaan.

\section{Metode}

Penelitian ini tergolong kualitatif dan merupakan studi kepustakaan, dan lokasamgraha menjadi objek material (OM). Penelitian ini menggunakan teknik pengumpulan data studi dokumen dari data utama dan pendukung yang berkorelasi terhadap OM yang menjadi tema kajian ini. Data utama studi ini antara lain; Modern Reading and Scientific..., Philosophy of the Bhagavad Gita..., The Bhagavad Gita for the 
Modern Reader..., sedangkan sumber pendukung adalah Principal Upanishads..., dan jurnal-jurnal yang relevan dengan tema penelitian.

Mengacu Bakker dan Zubair, penelitian ini menggunakan analisis data dengan teknis analisis deskriptif, interpretasi, holistik. Secara deskriptif, data mengenai nilai Loksamgraha paparkan secara sistematik supaya terjadi keterhubungan bahasa, gagasan dan menumbuhkan pemahaman kokoh. Pada level interpretasi, uraian tentang nilai Loksamgraha lebih lanjut akan telaah arti, nilai dan maksudnya. Operasionailsasi pada tahap interpretasi berpijak di temuan objektif untuk mendapatkan kebenaran tertinggi, bukan menurut selera interpreter. Selanjutnya pada tahap analisis holistika dimaksudkan agar kajian ini mendapatkan kebenaran yang menyeluruh, dikaji dari berbagai perspektif dan perjumpaan dengan realitas (Bakker \& Zubair, 1990:41).

\section{Hasil dan Pembahasan}

\section{Identitas Nasional}

Anthony Smith, seorang tokoh terkemuka dalam studi nasionalisme, menulis buku yang berjudul 'National Identity', dinyatakan bahwa nasionalisme, ideologi dan movement, harus terkait erat dengan identitas nasional. Sebuah konsep multi-dimensi, dan diperluas untuk memasukkan bahasa tertentu, sentimen dan simbolisme. Smith kemudian membuat daftar ciri-ciri dasar identitas nasional, yaitu: wilayah bersejarah, atau tanah air; mitos umum dan kenangan sejarah; budaya publik massal yang umum; hak dan kewajiban hukum bersama untuk semua anggota; ekonomi bersama dengan mobilitas teritorial bagi anggota. Menurutnya, rasa identitas nasional memberikan cara yang kuat untuk mendefinisikan dan menempatkan diri individu di dunia, melalui prisma kepribadian kolektif dan budaya yang khas. Identitas nasional adalah mekanisme untuk memberi orang rasa nilai individu dan kolektif, yang tanpanya mereka tidak dapat berfungsi (McCrone \& Bechhofer, 2015:10; Smith, 1991:vii, 14-17). Secara lebih eksplisit ia menjelaskan bahwa fungsi utama identitas nasional adalah menyediakan 'komunitas sejarah dan takdir' yang kuat untuk menyelamatkan orang dari pelupaan pribadi dan memulihkan keyakinan kolektif. Mengidentifikasi dengan bangsa berarti mengidentifikasi dengan lebih dari sekedar penyebab atau kolektivitas. Itu harus ditawarkan pembaruan pribadi dan martabat dalam dan melalui regenerasi nasional (Smith, 1991:161).

Bagi Schnabel dan Hjerm, identitas nasional seperti yang disadari oleh individu meliputi perasaan setia, persatuan, tindakan adalah lebih mendalam dibanding keyakinan atas ide persamaan. Dengan karakteristik sentral dari identifikasi dan rasa memiliki, keberlanjutan, kestabilan, identitas nasional dalam wujud agregatnya mampu berfungsi sebagai proxy untuk aspek khusus dari kohesi sosial (Schnabel \& Hjerm, 2014:3). Identitas nasional diciptakan melalui penyatuan dari pelbagai pluralitas identitas dalam masyarakat tanpa menegasikan keterikatannya. Identitas nasional merupakan simpul dari perseorangan dan pemerintah yang berkelindan. Ia berbeda dari komunitas, sebab komunitas berpotensi mendahulukan identitasnya daripada identitas nasional (Kymlicka, 2007:83; Widodo et al., 2015:5-6).

Beranjak dari Smith, Mc. Crone, Frank Bechhofer, Schnabel, Hjerm dan Widodo, dkk., maka dipandang penting untuk memberikan definisi identitas nasional secara konkrit sebagai basis wawasan bangsa Indonesia. Indentitas nasional dapat dieksplanasi ke dalam area identitas fundamental, yaitu Pancasila ideologi, basis norma, falsafah, perilaku berpolitik dan kerangka berpikir pembangunan. Berikutnya, identitas instrumental, UUD 1945 konstitusi negara, Bahasa Indonesia bahasa pemersatu, Garuda Pancasila lambang negara, Merah Putih bendara negara, Bhineka Tunggal Ika semboyan negara, dan Indonesia Raya lagu kebangsaan. Terakhir, identitas alamiah, mencakup Indonesia adalah archipelago dengan pluralitas suku, adat, budaya, bahasa dan agama (Afifah, 2018:187). 
Karakteristik dan jati diri bangsa tergambar dalam Identitas nasional. Pengetahuan ini membuka ruang pemahaman dan kesadaran setiap elemen bangsa atas keadaan dirinya sendiri. Secara personal, wawasan ini menjadi fundamen berpikir secara holistik bagi setiap elemen bangsa. Melalui pengertian ini ia dapat menakar setiap tindakannya dengan kadar yang tepat dalam konteks interaksi sosial dan bernegara. Dengan demikian, setiap individu berperan kontruktif dalam pergerakan kemajuan. Bagi negara, identitas nasional merupakan basis setiap kebijakan, arah, visi dan misi dalam mewujudkan cita-cita konstitusi. Baik individu, indentitas kelompok maupun negara, semuanya sinergi dalam pergerakan maju dalam rangka mewujudkan masa depan dan kepentingan bangsa secara menyeluruh.

\section{Politik Identitas}

Literatur ilmu politik memilah pemahaman antara politik identitas dan identitas politik. Pengertian yang pertama adalah sebuah gagasan yang meletakkan motivasi subjek dalam simpul kelompok politik, sedangkan kedua, lebih tertuju di wilayah politik pengelompokan identitas, meliputi pilihan politik atau golongan sosial sebagai instrumen. Morowitz memaknai politik ini (baca: politik identitas) sebagai batas antara yang diikutkan dan ditinggalkan. Heller mengartikan politik ini adalah suatu gerakan dimana perbedaan sebagai kategori utama, dengan propaganda toleransi dan kebebasan meskipun ujungnya akan menampakkan pola intoleransi dan konflik. Politik indentitas juga mencakup rasisme, bio-feminisme, environmentalism, persoalan etnis (Zahrotunnimah, 2018:93-94).

Politik identitas, secara konseptual merupakan gagasan serta tindakan politis guna memperoleh dan meneguhkan kuasa golongan sebagai komunitas politik, entah melalui aturan demokrasi sebagaimana kontestasi elektoral diberbagai bentuk dan tingkatan dengan memanfaatkan isu identitas. Perbedaan itu dimanfaatkan sebagai instrumen politik dengan tujuan berkuasa oleh pihak tertentu. Politik jenis ini mengeksploitasi perbedaan demi hasrat kuasa. Persoalan timbul kemudian apakah elit politik telah secara tuntas mengartikan hakikat dalam identitas tersebut. Pertanyaan selanjutnya, siapakah yang sangat berhak atas identitas guna kepentingan politik, mengingat identitas etnik, sosial, religi pada dasarnya tidaklah satu dengan demikian tidak bisa diakui oleh salah satu identitas. Orientasi berpolitik sebagaimana dimaknai demikian menjadi kontra produktif, utamanya pada tujuan berdemokrasi atau bernegara. Karena, ideal politik adalah untuk menata kehidupan bersama dalam rangka menggapai tujuan kolektif (Rantung, 2019:3).

Dalam kontek ke-Indonesia-an, aktualisasi politik bernegara harus selaras dengan nilai-nilai falsafat Pancasila, yaitu religiusitas, humanisme, ketunggalan, dialog, dan keadilan (Lesilolo, 2018:75), atau menurut gagasan politik John Rawls dalam $A$ Theory of Justice, dinyatakan sebagai fairness, yakni; a. kompetensi untuk memahami dan bertindak yang didasarkan atas rasa keadilan dan dorongan untuk mengupayakan kolaborasi atau kerjasama sosial, b. kompetensi dalam mengkreasi, inovasi secara logis mengupayakan terciptanya gagasan baik, oleh Rawls menyebutnya a sense of the good (Hasanuddin, 2018:203-204).

Terminologi politik identitas sesungguhnya lahir di awal 70-an abad lalu. Namun esensi dari maksudnya telah ada jauh sebelumnya dan menjadi faktor sejarah dari arena kontestasi politik, terminologinya adalah populisme. Jika politik identitas merujuk tindakan politis berbasis identity, 'populisme' lebih pada gerakan rakyat berbasis identitas yang memotivasi politik identitas. Populisme merupakan politik populus, sebuah bangsa, kelompok meminta untuk diakui eksistensinya. Mereka menampakkan kolektivitas, guna menunjukkan diri. Ketidakadilan adalah alasan pokoknya. Keduanya, (politik identitas, populisme) menyoal diskriminasi, ketidakadilan. 
Ketertindasan, pengabaian, penghinaan, diskriminasi adalah basis dari Populisme, sedangkan politik identitas merupakan upaya politis atas keadaan yang mereka rasakan itu, sebuah upaya dalam rangka mendapatkan pengakuan dan keadilan. Jadi, tujuannya tidak bersifat politik, ekonomi, dan administratif. Ia menolak merunduk pada penindasan penguasa, justru mendongak. Ikrar sumpah pemuda dari semangat ini, sebuah kesadaran akan kesamaan identitas sebagai bangsa Indonesia. Demikianlah populisme Indonesia (Suseno, 2018:8).

Berbeda dengan bangsa yang cenderung homogen, seperti Polandia yang beragama Katolik hampir 100 persen, dan berbahasa Polandia, kebangsaan mereka sangat jelas dan begitu alami. Kenyataan ini berbeda dengan Indonesia yang sangat memiliki identitas kebangsaan yang sangat majemuk, baik itu bahasa, adat, budaya, religi, ras, dan etnis. Perbedaan itu natural, namun menyatu. Solidaritas yang lahir dari pengalaman ketertindasan bersama. Lahirnya bangsa Indonesia ditandai momentum Sumpah pemuda. Kesatuan bangsa ini bersifat etik, tidak natural. Persatuan yang didasarkan keinginan luhur, keinginan bermartabat dan merdeka yang dibingkai pada satu pemahaman tidak atas kekhasan bahasa, ras, religi, melainkan tuntutan agar diakui sebagai manusia.

Indonesia telah menggapai tujuannya, yakni kemerdekaan yang telah diakui dunia. Karenanya, wacana politik identitas menjadi kurang relevan. Manakala suatu bangsa atau komunitas telah usai dari ketertindasan dan ketidakadilan, maka politik identitas telah kehilangan maknanya. Jika identitas telah terang, maka politik identitas adalah gambaran mentahnya emosi, nasionalisme dan kebudayaan. Pancasila, UUD 1945 adalah pandangan hidup dan fundamen bernegara menjadi pijakan penting berbangsa. Pancasila juga adalah sumber hukum dimana aktualisasinya juga didasarkan atas asas kekelurgaan, keadilan, bersendikan nilai-nilai agama walau bukan teokrasi atau sekuler. Sebuah hukum yang merupakan cerminan budaya masyarakat, dan hukum yang bersifat netral dan universial. Karenanya, segenap persoalan yang ada dituntaskan dalam norma perpolitikan Indonesia yang telah dibentuk, sehingga mengacu hukum. Perbaikan, pengembangan hukum dilakukan seperlunya, berdasarkan UUD, dan akhirnya tetap dalam spirit Pancasila. Karenanya, tidak ada lagi politik identitas dalam tubuh bangsa Indonesia. Identitas bangsa Indonesia, 'bhineka tunggal ika' atas dasar Pancasila telah begitu terang (Rahmatullah, 2020:39; Suseno, 2018:10; Umarhadi et al., 2020:3).

Menguatnya bahasa identitas beberapa tahun belakangan adalah kemunduran. Kebebasan demokrasi selewengkan dengan memanfaatkan identitas untuk hasrat kekuasaan, utamanya eksploitasi identitas religi. Jika etnis, suku memiliki limitasi teritorial, religi sama sekali berbeda. Semua memiliki identitas agama, dan apabila hal itu dijadikan instrumen untuk memisahkan antara lawan dan kawan, persatuan bangsa akan porak-poranda. berbagai kajian menunjukkan, politik ini mempertontonkan aksi intoleran, anti pluralisme, menguatkan sikap absolutisme, serta melegitimasi kekerasan sebagai pemecahan masalah. Penyelesaian persoalan bangsa yang berkaitan dengan identitas tertentu hendaknya diselesaikan melalui mekanisme norma, konstitusi, dan telah didirikan dengan rasa tanggungjawab bersama. Memanfaat persoalan yang berkaitan dengan identitas tertentu untuk menginisasi gerakan populis untuk memperoleh keuntungan politik adalah tidak etis, tidak jujur. Karena, persoalan itu tidak hendak diselesiaikan melainkan dijadikan titian untuk menggapai hasrat politis (Shofan, 2018:4; Suseno, 2018:12-13).

\section{Relevansi Nilai Lokasamgraha terhadap Wacana Politik Identitas dan Masa Depan Kebangsaan}

Sekilas telah dijelaskan mengenai politik identitas (political of identity). Hal yang tidak kalah penting untuk diketahui sebelum berbicara lebih lanjut tentang lokasamgraha 
adalah pertanyaan, masa depan kebangsaan yang bagaimana yang ingin kita raih? Penjelasan ini memberikan gambaran terhadap apa yang hendak kita capai. Kabar baiknya, rumah masa depan Indonesia yang kita semua ingin capai sekurang-kurangnya termasuk dalam Pancasila serta UUD 1945. Ideal masa depan kebangsaan terurai dalam lima prinsip dasar dalam sila Pancasila.

Sila-sila ini kemudian dijadikan landasan filsofi, ideologi guna menggapai ideal negara, yang dinyatakan dalam UUD 1945, yakni melindungi bangsa, tumpah darah Indonesia, mewujudkan kesejahteraan, mencerdaskan bangsa, berpastisipasi dalam perdamaian dunia berlandaskan kemerdekaan, perdamaian, dan keadilan (Asshiddiqie, 2011:3-5; Rahmatullah, 2020:41).

Perbincangan terhadap fenomena politik identitas yang belakang ini menguat menjadi kegelisahan bagi kalangan yang di Indonesia. Wacana politik identitas sebelumnya adalah perihal yang kurang terpahami, khususnya bagi masyarakat awam. Namun pada momentum Pilkada DKI Jakarta pada 2017 silam, definisi yang tadinya abstrak telah benar-benar dipahami hingga sampai pada ruang sanubari yang paling dalam. Hal ini mengingatkan kembali ke pada satu perhelatan pemilihan gubernur Californalia tahun 1982. Ketika itu harian San Fransicco Chronicle dalam headline-nya yang bertajuk Bredley Win Projected, tepat sehari pasca pemilihan, diumumkan bahwa T. Bradley, mantan Walikota LA, berkulit hitam sangat diunggulkan dari Partai Demokrat sebagai jawara sebelum perhitungan resmi. Keberanian itu didasarkan pada hasil penelitian dan exit poll yang memprediksi Bradley akan menang signifikan. Namun pada rilis perhitungan resmi menyatakan berbeda, justru G. Deukmejian dari Partai Republik menjadi pemenang. Kekalahan Bradley kuat diduga karena faktor ras. Peristiwa itu, oleh para ahli survei kemudian dikenang sebagai Bradly effect, tatkala kulit putih di teliti, ia menyimpan sikap penolakannya pada Bradley karena enggan dituduh rasis (Muhtadi, 2018:67-68).

Sebagaimana telah dinyatakan oleh beberapa intelektual bahwa politik identitas berpotensi besar meruntuhkan persatuan bangsa karena cara kerjanya yang mengekploitasi perbedaan untuk hasrat politik dan kekuasaan kelompok tertentu. Persoalan ini juga menggema di kalangan agamawan, terlebih praktik-praktik politik identitas yang terjadi belakangan ini menggunakan isu identitas agama. Karenanya, pandangan agamawan dan tokoh muda khususnya dalam menyikapi persoalan ini memiliki urgensinya saat ini, dan berikut ini adalah pandangan dari seorang penganut Hindu.

Pembahasan yang bersentuhan dengan tema pemerintahan (politik) dalam kitab suci Hindu terdapat di Veda bagian Smrti, diantaranya; kitab Arthasastra, Itihasa (Ramayana, Mahabharata), Purana, Dharma Sastra (Parasara Dharmasastra, Manawadharasastra), Nitisastra, dan seterusnya. Pembahasan secara menyeluruh perihal politik dan pemerintahan tentu tidak dapat dilakukan di sini, karenanya akan dibahas dari satu bagian dari kitab di atas, yakni lokasamgraha, yang merupakan satu nilai yang bertautan dengan ideologi dan sikap politik dalam kitab Bhagavad Gita yang merupakan bagian, dari salah satu Parva (bagian) di dalam kitab Mahabharata, yakni Bhismaparva. Untuk diketahui bahwa kitab Mahabharata di dalamnya terdiri atas delapan belas bagian (Astadasa Parva). Bhagavad Gita berisi delapan belas bab (adhyaya), dengan 700 Sloka (ayat). Pembahasa mengenai lokasamgraha terdapat dalam adhyaya (bab) ketiga, yakni Karma Yoga. Bhagavad Gita berisi jebaran pengetahuan yang disampaikan secara oleh Sri Krishna kepada Arjuna, sesaat sebelum Bharata Yudha, di Kuru Ksetra (Saraswati, 2009:17; Titib, 1996:107).

Terlebih dahulu akan disinggung mengenai leadership, relasi kekuasaan dan negara secara implisit dijelaskan dalam kitab Nitisastra I.10, di satu sisi singa sebagai 
penjaga hutan, namun ia juga di jaga hutan. Apabila kedunya bertengkar, hingga singa meninggalkan hutan, maka hutan itu akan rusak karena pohon-pohon hingga tak bersisa, dan singa tidak memiliki tempat persembunyian lagi dan menjadi buruan untuk dibinasakan (Miswanto, 2015:118-119): Penjelasan yang ada di dalam Nitisastra di atas, juga terdapat di dalam kitab Kakawin Nagara Krtagama, 89.2, diandaikan bahwa sebuah negara dan wilayahnya ibarat singa dan hutan. Jika wilayah-wilayah itu dirusak, maka negara akan mengalami krisis pangan. Jika tidak memiliki alat negara yang tangguh, maka negara-negara dari luar akan dengan mudah menakhlukkannya, oleh sebab itu keduanya hendaknya dijaga dan

Kedua sloka (ayat) di atas menerangkan bahwa kekuasaan dan negara itu bersifat sinergi. Kekuasaan yang direpresentasikan dalam figur pemimpin dalam rangka pencapaian tujuan negara kepada rakyatnya. Dalam konteks bangsa Indonesia, kekuasaan adalah sebuah kekuatan kepemimpinan yang memastikan amanat konstitusi berjalan dengan baik. Kekuasaan itu bekerja dalam dimensi universal, bukan partikular, untuk kepentingan seluruh rakyat bukan sebagian sebagian kelompok. Penyimpangan terhadap amant itu, maka pemimpin telah menghianati konstitusi dan negara. Ia telah menyimpang dari kodrat spiritualnya sebagai 'perpanjangan tangan Tuhan' untuk berbuat demi kesejahteraan masyarakat, karenanya ia tidak berjalan pada rel kebenaran (adharma). Pesan mengenai hal ini dinyatakan dalam kitab Yajurveda XX.3 dan IX.22, dimana pemimpin memiliki peran yang sangat penting. Ia dinobatkan guna memastikan kemakmuran, kekuatan, dan kemasyuran bagi masyarakat yang dipimpinnya. Demikian pula Yajurveda XX.3, menerangkan eksistensi pemimpin adalah figur yang mampu membawa kemakmuran, kesejahteraan, perkembangan, sosok yang mampu menjaga dan lindungi. Pemimpin merupakan role model yang memiliki karakter mulia, teguh hati dan mawas diri (Titib, 1996:476).

Sekarang akan dibicarakan mengenai lokasamgraha. Nilai ini dijelakan dalam kitab Bhagavadgita, adhyaya III sloka 19, 20 dan 25. Diuraikan bahwa di dalam tingkatannya, kerja dilakukan orang adalah paling mulia jika dilakukan tanpa motivasi untuk mendapatkan ganjaran untuk kepentingan pribadinya. Demikian juga tindakan yang disertai dengan persembahan sebagai wujud bhakti, jauh lebih mulia karena akan membawa pada kebahagiaan yang tertinggi. Contoh yang diberikan dalam penjelasan sloka (20) ini adalah Raja Janaka. Ia adalah figur pemimpin yang melakukan pekerjaan semata-mata demi kepentingan masyarakatnya, demi kepentingan umum (lokasangraham) bukan dirinya sendiri. Krishna menyatakan bahwa apa yang dilakukan oleh Raja Janaka patut dijadikan teladan dalam setiap tindakan. Pada sloka 25, disampaikan perbedaan orang yang bodoh dan yang bijaksana. Orang bodoh bekerja karena sematamata ganjaran untuk kepuasan dirinya sendiri, tanpa memikirkan orang lain. Sebaliknya tindakan orang yang pandai dan bijaksana melakukan tindakan dengan niatan untuk memberikan sebanyak-banyaknya manfaat bagi orang lain, untuk kesejahteraan manusia

pada umumnya (loka-sangraham) (Maitra, 2018:66; Nadkarni, 2017:194; C. Radhakrishnan, 2018:85):

Lokasamgraha dalam Bhagavad Gita, adalah satu pembahasan penting dalam Hindu yang bertalian dengan Karma Yoga. Apa itu Karma Yoga? Karma Yoga adalah ajaran tentang filsafat tindakan dalam Hindu. Karma berarti bertindak (action), yoga dari akar kata $y u j$ artinya menghubungkan (dengan Tuhan). Karma Yoga adalah satu dari beberapa cara mendekatkan diri dengan Tuhan melalui karma atau tindakan. Manusia mendedikasikan tindakannya semata-mata untuk dipersembahkan kepada Sang Pencipta. Keterhubungan dengan Tuhan dirajut melalui jalan tindakan tanpa kemelekatan akan hasil dan motivasi pribadi lainnya, melainkan untuk kepentingan dan kesejahteraan umum atau dunia. 
Nilai lokasamgraha di awali dari sikap keraguan Arjuna sesaat sebelum Bharata Yudha. Keraguan Arjuna sangat beralasan mengingat yang ia hadapi adalah saudaranya sendiri (Kaurava), bahkan Dronacharya, Rsi Bhisma adalah guru dari kelima Pandava yang sangat dihormati. Di samping itu disana juga terdapat Raja Angga Karna yang merupakan saudara kandung Pandava. Secara identitas, kedua belah pihak adalah saudara, satu identitas. Arjuna merasa malu harus melawan keluarga demi sebuah tahta Hastina pura. Ia merasa dirinya terlalu rakus dan tidak bermoral, seolah-olah mengabaikan hubungan keluarga, mengesampingkan pertimbangan moral demi hasrat kekuasaan. Dilema itulah yang menjadi awal dari seluruh perbincangan dalam Bhagavad Gita. Pada akhirnya Sri Krihna menunjukkan satu wawasan penting bahwa Bharata Yudha bukanlah semata-mata sebuah perebutan kekuasaan atau ketamakan sebuah tahta kerajaan. Hal penting yang menjadi satu alasan mengapa bharata yudha ini terjadi adalah semata-mata untuk membebaskan ketertindasan bangsa Hastinapura dari tirani Kaurava, yang direpresentasikan oleh Duryodana dan para pendukung politiknya. Pembahasan itu mengurai tentang filsafat tindakan yang kemudian memunculkan satu terminologi yang saat ini sedang diperbincangkan, lokasamgraha.

Pada adhyaya III sloka (ayat) 19 di atas, dalam tingkatannya, kerja paling mulia yang dilakukan seseorang apabila dijalankan bukan dengan tujuan semata-mata untuk memperoleh keuntungan pribadi. Setiap tindakan dengan motivasi bhakti kepada Tuhan dapat mengangkat seseorang menuju kemurnian, sempurnanya pikiran dan jiwa, karenanya hal itu membawa ke kebahagiaan tertinggi. Selanjutnya pada adhyaya III sloka (ayat) 20, istilah lokasamgraha dimaknai for the welfare of the world, untuk kesejahteraan dunia. Di sini Krishna memberikan teladan figur mulia dimana tindakannya didedikasikan untuk kepentingan dan kebahagiaan orang lain, yaitu Raja Janaka pemimpinan kerajaan Mithila, ayah Dewi Sita permaisuri kerajaan Ayodhya. Ia disebut memiliki karakter acarya. Di masa hidupnya, ia mencapai kesadaran jiwa dan kebahagiaan dalam aktivitas kerjanya, tanpa motivasi untuk kepentingan pribadi, hingga dirinya berpulang. Keakuan itu telah lenyap darinya. Tatkala istananya terbakar, ia berucap, 'tidak suatupun milikku terbakar' (Maitra, 2018:66; Mantik, 2007:61-62; Nadkarni, 2017:194; Pendit, 1996:9596; C. Radhakrishnan, 2018:85).

Menanggapi Bhagavad Gita, adhyaya III sloka 25, Nadkarni berpandangan bahwa seluruh tujuan Bhagavad Gita dapat dikatakan untuk menunjukkan bagaimana memperoleh kebahagiaan yang langgeng setelah kebutuhan dasar terpenuhi. Jika kebutuhan dasar makanan, papan, sandang, kesehatan, dan beberapa pendidikan tidak terpenuhi, tidak ada pertanyaan untuk memperoleh kebahagiaan yang lebih tinggi. Meskipun perhatian utama Bhagavad Gita adalah dengan kebahagiaan yang lebih tinggi di luar pemenuhan kebutuhan dasar, itu tidak mengabaikan kebutuhan orang akan kesejahteraan atau kesejahteraan. Ini secara eksplisit menyarankan bahwa seseorang harus memiliki makanan dan tidur yang cukup, tidak makan terlalu sedikit (atau terlalu banyak), dan menyerukan kepada semua orang yang memiliki cukup makan dan memiliki kelebihan, untuk bangkit untuk memenuhi kebutuhan dasar orang lain melalui penekanannya tentang lokasamgraha atau kesejahteraan rakyat. Karena dikatakan ada keilahian dalam semua makhluk, itu menekankan nilai rasa hormat yang penuh kasih untuk semua dan pelayanan tanpa pamrih.

Inilah filosofi Bhagavad Gita yang diekspresikan dalam konsep karma-yoga dan lokasamgraha. Gandhi terinspirasi oleh filosofi ini dan mengembangkan konsep perwaliannya. Mengikuti ajaran ini berarti berorientasi pada kepentingan umum, serta diri dalam kemajuan spiritual. Namun demikian, fokus utama Bhagavad Gita adalah membimbing orang untuk mencapai tingkat kebahagiaan yang lebih tinggi jauh melampaui keberadaan hewan, tanpa merusak pemenuhan kebutuhan dasar. Bahkan 
setelah kebutuhan dasar terpenuhi, tanpa henti mengejar kebahagiaan lebih lanjut melalui kenikmatan indria bisa jadi tidak ada habisnya dan membuat frustrasi. Bhagavad Gita menunjukkan pilihan terbaik bagi kebahagiaan yang nyata dan lebih tinggi (Nadkarni, 2017:194-195).

Dalam relevansinya dengan politik identitas, Nilai lokasamgraha dua hal yang lebih terlihat tidak dalam kesejalanan. Jika politik identitas lebih pada kerja-kerja yang mengeksploitasi perbedaan dan berorientasi pada tujuan yang bersifat partikular, lokasamgraha justru pada posisi yang sebaliknya merangkul perbedaan masyarakat ke dalam persatuan dan orientasi akhirnya adalah kesejahteraan masyarakat (for the welfare of the world). Secara historis, lokasamgraha lebih pada satu perjuangan melawan ketertindasan satu bangsa dari tirani kekuasaan, Kaurava. Lokasamgraha juga merupakan sebuah perjuangan untuk kepentingan bersama, bukan perseorangan atau kelompok. Satu hal yang penting dari semangat ini (lokasamgraha) adalah esensinya yang berorientasi pada universalistas, kepentingan umum atau dunia, bukan sebaliknya. Satu prinsip yang berbeda dengan apa yang dipertontonkan oleh apa yang belakangan ini dibahasakan sebagai politik identitas.

Lokasamgraha yang dimaksud ini, tidaklah terlepas dari landasan etis dari Hindu yang tertuang di dalam kitab Chandogya Upanisad 8.8.7, yang menarik keragaman entitas hidup pada satu hakikat kesetaraan, yang sesungguhnya tidak mengenal perbedaan, yakni Atman, yang merupakan sari yang paling halus (akar dari semua keberadaan), seluruh alam semesta ini menjadikannya sebagai atman-nya. Itu merupakan kebenaran, itulah atman tat tvam asi, demikian dinyatakan Uddalaka kepada putranya, Svetaketu (S. Radhakrishnan, 1968:458).

Itu adalah kamu, demikian makna dari tat tvam asi. Aphorisme masyhur ini menitikberatkan aspek ilahiah dari jiva. Ia yang mengenal dirinya sebatas tubuh dan pikiran, hanya mengenal dirinya yang paling luar bukan diri sejati. Aphorisme ini mengarah pada entitas yang berada dalam bukan pada jiva emiprik dengan atribut. Aurobinda mengatakan, Isa merupakan hakikat keilahian yang berada di seluruh kosmos. Chandogya Upanisad 3.14.1, menerangkan sesungguhnya semesta ini Brahman (Aurobindo, 2003:21; Joyo \& Maharani, 2021:20; Joyo \& Murtiningsih, 2021:67; S. Radhakrishnan, 1968:458). Landasan etik Hindu yang berikutnya adalah tentang sikap non diskrimantif, tertuang di dalam Bhagavad Gita, Adhyaya V sloka (ayat) 18, "orang arif bijaksana melihat segala sesuatu dalam visi setara, entah itu orang mulia maupun orang yang hina sekalipun" (Pendit, 1996:154).

Nilai lokasamgraha tidak dalam pandangan melihat segala sesuatu dalam perbedaan identitas tertentu, melainkan satu nilai yang justru melampaui entitas perbedaan itu dalam satu kemanunggalan yang utuh dan menyeluruh. Politik identitas yang sedang diperbincangkan saat ini merupakan satu wacana kontraposisi dari nilai Lokasamgraha. Lokasamgraha bersama dengan landasan etis Hindu tidak menyisakan ruang perdebatan terhadap perbedaa entitas dan identitas, karena hal itu dipandang telah usai. Selanjutnya, dalam wacana masa depan kebangsaan, nilai lokasamgraha, bersama dengan landasan etis Hindu, tat tvam asi menemukan resonansi yang sama. Nilai ini adalah salah satu dari universalitas Hindu yang dapat dijadikan sebagai sumbangsih pengetahuan dan kebijaksanaan dalam mewujudkan masa depan kebangsaan Indonesia. Sebagai wacana kebangsaan, eksalasi politik indentitas harus dijawab dengan gagasan universal agamaagama dan sikap moderasi, dengan demikian politik identitas pada akhirnya dapat dipahami sebagai gerakan politik yang tidak relevan dengan situasi kebangsaan, dan berpotensi meruntuhkan persatuan dan masa depan kebangsaan. 


\section{Kesimpulan}

Kajian ini menyimpulkan: 1) Identitas nasional adalah bhineka tunggal ika atas dasar Pancasila, UUD 1945, namun secara garis besar di bagi menjadi tiga; identitas fundamental, identitas instrumental, dan identitas alamiah. 2) Politik identitas secara historis berlatar belakang ketertindasan sebuah bangsa atau komunitas. Indonesia yang telah memperoleh kedaulatannya dan konstitusi negara yang telah memberikan jaminan keadilan kepada semua elemen bangsa, maka politik identitas telah kehilangan maknanya. Eskalasi politik indentitas yang muncul akhir-akhir ini dipandang sebagai ancaman dan sabotase dari eksistensi bangsa. 3) Lokasamgraha merupakan kebijaksanaan Hindu yang tertuang di dalam Bhagavad Gita pada adhyaya III yang mengulas filsafat tindakan (karma yoga). Lokasamgraha di dalam praksisnya dapat pula diterjemahkan sebagai bentuk sikap politik dan landasan etis, yang secara filosofis dimaksudkan sebagai tindakan atau perjuangan, termasuk di dalamnya adalah perjuangan politik yang berorientasi kepentingan umum, kesejahteraan masyarakat, dan tidak memihak pada tujuan kelompok (identitas) tertentu. Karenanya, kebijaksanaan ini berseberangan dengan semangat politik identitas yang berorientasi pada kepentingan parikular. Lokasamgraha ia memiliki kesamaan visi dan resonansi dengan wacana masa depan kebangsaan yang memiliki komitmen dan cita-cita memajukan bangsa dan negara.

\section{Daftar Pustaka}

Afifah, T. (2018). Identitas Nasional Di Tinjau dari Undang-Undang Dasar 1945 dan Undang-Undang Nomor 24 Tahun 2009. Ajudikasi : Jurnal Ilmu Hukum, 2(2), 187. https://doi.org/10.30656/ajudikasi.v2i2.903

Al Qurtuby, S. (2018). Sejarah Politik Politisasi Agama dan Dampaknya di Indonesia. MAARIF , 13(2), 43-54. https://doi.org/10.47651/mrf.v13i2.21

Asshiddiqie, J. (2011). Membudayakan nilai-nilai pancasila dan Kaedah-kaedah Undangundang Dasar Negara RI tahun 1945. Kongres Pancasila III.

Aurobindo, S. (2003). Isha Upanishad. Sri Aurobindo Ashram Publication Departement.

Badan Pusat Statistik. (2020). Proyeksi Jumlah Penduduk Indonesia 2020. In Databoks. https://databoks.katadata.co.id/datapublish/2020/01/02/inilah-proyeksi-jumlahpenduduk-indonesia-2020

Bakker, A., \& Zubair, A. C. (1990). Metodologi Penelitian Filsafat. Kanisius.

Hasanuddin, I. (2018). Keadilan Sosial: Telaah atas Filsafat Politik John Rawls. Refleksi, 17(2), 193-204. https://doi.org/10.15408/ref.v17i2.10205

Joyo, P. R., \& Maharani, S. D. (2021). The Concept of Value in Religious Plurality In Indonesia (Reflection on Verses of Íśā Upanișad). Vidyottama Sanatana: International Journal of Hindu Science and Religious Studies, 5(1), 11-22.

Joyo, P. R., \& Murtiningsih, S. (2021). Relevansi Ontologi Brahman dan Ātman dalam Kitab İșāvasya Upanișad dengan Pluralitas Agama di Indonesia. Jurnal SMART (Studi Masyarakat, Religi, Dan Tradisi), 7(01), 57-70. https://doi.org/10.18784/smart.v7i01.1228

Kawangung, Y. (2019). Religious moderation discourse in plurality of social harmony in Indonesia. International Journal of Social Sciences and Humanities, 3(1), 160 170. https://doi.org/10.29332/ijssh.v3n1.277

Khamdan, M., \& Wiharyani, W. (2018). Mobilisasi Politik Identitas dan Kontestasi Gerakan Fundamentalisme. Al-Tahrir: Jurnal Pemikiran Islam, 18(1), 193. https://doi.org/10.21154/altahrir.v18i1.1198

Kymlicka, W. (2007). Multicultural Odysseys: Navigating the New International Politics of Diversity. Oxford University Press. 
Lesilolo, H. J. (2018). Kajian Filsafat Pancasila Dalam Pendidikan Multikultural Di Indonesia. KENOSIS: Jurnal Kajian Teologi, 4(1), 74-88. https://doi.org/10.37196/kenosis.v1i1.22

Maitra, K. (2018). Philosophy of the Bhagavad Gita: A Contemporary Introduction. Bloomsbury Academic.

Mantik, A. S. (2007). Bhagavad Gita. Paramita.

Masyrullahushomad, M. (2019). Mengokohkan Persatuan Bangsa Pasca Konflik Bernuansa Agama Di Ambon Dan Poso. ISTORIA: Jurnal Pendidikan Dan Ilmu Sejarah, 15(1). https://doi.org/10.21831/istoria.v15i1.24378

McCrone, D., \& Bechhofer, F. (2015). Understanding National Identity. Cambridge University Press.

Miswanto. (2015). Kakawin Nitisastra: Teks, Terjemahan dan Komentar. Paramita.

Muhtadi, B. (2018). Politik Identitas dan Mitos Pemilih Rasional. MAARIF, 13(2), 68-86. https://doi.org/10.47651/mrf.v13i2.23

Muhtar, F. (2019). The Resolution of Religious Controversy in Multicultural Society in Indonesia. Al-Tahrir: Jurnal Pemikiran Islam, 18(2), 395. https://doi.org/10.21154/altahrir.v18i2.1381

Na'im, A., \& Syaputra, H. (2011). Kewarganegaraan, Suku Bangsa, Agama dan Bahasa Sehari-Hari Penduduk Indonesia (Hasil Sensus Penduduk 2010). Badan Pusat Statistik. https://media.neliti.com/media/publications/49956-IDkewarganegaraan-suku-bangsa-agama-dan-bahasa-sehari-hari-pendudukindonesia.pdf

Nadkarni, M. V. (2017). The Bhagavad-Gita for the Modern Reader: History, interpretations and philosophy. Routledge.

Pendit, N. S. (1996). Bhagavad Gita. Hanuman Sakti.

Radhakrishnan, C. (2018). Bhagavad Gita: Modern Reading and Scientific Study (Second Edi). Hi-Tech Books.

Radhakrishnan, S. (1968). The Principal Upanishads. George Allen \& Unwin LTD.

Rahmatullah, I. (2020). Meneguhkan Kembali Indonesia Sebagai Negara Hukum Pancasila. 'ADALAH, 4(2). https://doi.org/10.15408/adalah.v4i2.16108

Rantung, D. D. A. (2019). TEOLOGI POLITIK UNTUK KEADILAN: Respons Teologis Gereja di Tengah Menguatnya Politik Identitas. Voice of Wesley: Jurnal Ilmiah Musik Dan Agama, 2(1). https://doi.org/10.36972/jvow.v2i1.21

Romli, L. (2019). Political Identity and Challenges for Democracy Consolidation in Indonesia. Politik Indonesia: Indonesian Political Science Review, 4(1), 78-98. https://doi.org/10.15294/ipsr.v4i1.17214

Roza, E. (2017). Maritim Indonesia, Kemewahan Yang Luar Biasa. Kementrian Kelautan Dan Perikanan Republik Indonesia, 2. https://kkp.go.id/artikel/2233-maritimindonesia-kemewahan-yang-luar-biasa

Saraswati, S. C. (2009). Peta Jalan Veda (N. P. Putra (ed.)). Media Hindu.

Schnabel, A., \& Hjerm, M. (2014). How the Religious Cleavages of Civil Society Shape National Identity. SAGE Open, 4(1), 215824401452541. https://doi.org/10.1177/2158244014525417

Shofan, M. (2018). Politisasi Agama di Ruang Publik: Ideologis atau Politis? MAARIF, 13(2), 3-6. https://doi.org/10.47651/mrf.v13i2.17

Siswanto, S. (2019). Pancasila Sebagai Pengawal Solidaritas Kebangsaan. Jurnal Pertahanan \& Bela Negara, 9(1), 109. https://doi.org/10.33172/jpbh.v9i1.502

Smith, A. D. (1991). National Identity. Pinguin Books Ltd.

Suseno, F. M. (2018). Politik Identitas? Renungan Tentang Makna Kebangsaan. MAARIF, 13(2), 7-13. https://doi.org/10.47651/mrf.v13i2.18 
Titib, I. M. (1996). Veda Sabda Suci Pedoman Praktis Kehidupan. Paramita.

Triguna, I. B. . Y. (2019). KEBHINEKAAN BANGSA INDONESIA: Urgensi dan Relevansinya dalam Era Revolusi Industri 4.0. Dharmasmrti: Jurnal Ilmu Agama Dan Kebudayaan, 10(2), 46-52. https://doi.org/10.32795/ds.v19i2.426

Umarhadi, Y., Lasiyo, ., \& Santoso, H. (2020). The conception of human nature according to Notonagoro and Drijarkara and their implications for the development of the Philosophy of Pancasila. Research, Society and Development, 9(11), e1659119659. https://doi.org/10.33448/rsd-v9i11.9659

Widodo, W., Anwari, B., \& Maryanto. (2015). Pendidikan Kewarganegaraan. Andi.

Zahrotunnimah, Z. (2018). Sejarah Politik Identitas dan Nasionalisme di Indonesia. 'ADALAH, 2(10). https://doi.org/10.15408/adalah.v2i10.9437 